\title{
Insulin inhibits leptin receptor signalling in HEK293 cells at the level of janus kinase-2: a potential mechanism for hyperinsulinaemia-associated leptin resistance
}

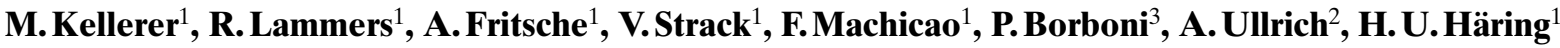 \\ ${ }^{1}$ Eberhard-Karls University of Tübingen, Internal Medicine IV, Tübingen, Germany \\ ${ }^{2}$ Max-Planck Institut for Biochemistry, Martinsried, Germany \\ ${ }^{3}$ Laboratory of Molecular Medicine, Department of Internal Medicine, University of Rome, Rome, Italy
}

\section{Abstract}

Aims/hypothesis. Leptin resistance in obese humans seems to be predominantly caused by signalling abnormalities at the post receptor level. Leptin resistance in obese individuals is frequently associated with insulin resistance and pronounced hyperinsulinaemia indicating a negative crosstalk of the insulin and leptin signalling chain.

Methods. This hypothesis was tested using a cell model of peripheral leptin signalling, i.e. insulin-secreting cell lines (RINr1046-38). Mechanisms for a crosstalk between the insulin and leptin signalling pathway were also studied in rat- 1 and HEK293 cells overexpressing elements of the insulin and leptin signalling chain.

Results. The effects of leptin on insulin secretion are completely cancelled by a 4-h preincubation with 1 $\mathrm{nmol} / \mathrm{l}$ insulin, supporting the hypothesis of a negative crosstalk of insulin and leptin signalling. We investigated the potential molecular mechanisms in more detail in HEK293 cells and Rat-1 fibroblasts that overexpressed proteins of the insulin and leptin signalling chain. Leptin $(60 \mathrm{ng} / \mathrm{ml})$ stimulated autophosphorylation of JAK-2 in HEK 293 cells. This leptin effect could be inhibited by simultaneous treatment of cells with insulin. Furthermore, overexpression of the insulin receptor in HEK 293 cells clearly reduced JAK-2 phosphorylation and led further downstream to a diminished phosphatidylinositol 3kinase activity. The inhibitory effect of the insulin signal could be partially prevented by transfection of the cells with an inactive mutant of the tyrosine phosphatase SHP-1.

Conclusion/interpretation. In summary, our data suggest that the insulin receptor signalling pathway interferes with leptin signalling at the level of JAK-2. Inhibition of JAK-2 phosphorylation might occur through SHP-1-dependent pathways, indicating that hyperinsulinaemia contributes to the pathogenesis of leptin resistance. [Diabetologia (2001) 44: 1125-1132]

Keywords Insulin receptor, leptin receptor, janus kinase, insulin secretion, leptin, insulin.
Received: 23 November 2000 and in revised form: 8 May 2001

Corresponding author: Dr. H. U.Häring, Eberhard-Karls-Universität Tübingen, Innere Medizin IV, Otfried-Müller Str. 10, D-72076 Tübingen, Gemrany

Abbreviations: IR, Insulin receptor; HIR, human insulin receptor; HEK, human embryonic kidney; RIN, rat insulinoma; JAK, janus kinase; SHP, src homology containing phosphatase; STAT, signal transducer and activator of transcription; IRS, insulin receptor substrate; PI 3-kinase, phosphatidyl inositol 3kinase; SDS-PAGE, sodium dodecyl sulfonyl-polyacrylamide gel electrophoresis; EGF, epidermal growth factor; PDGF, platelet derived growth factor
The role of leptin in the pathogenesis of obesity has been intensively studied in recent years [1]. Many studies in obese patients found an apparent discrepancy between circulating leptin levels and leptin effects, suggesting that leptin resistance might be a common phenomenon in obese individuals [1]. The mechanisms causing leptin resistance are not, however, clear. Structural defects of the leptin receptor, associated with a loss of function which might cause cellular leptin resistance, do not seem to be a common cause in human beings [2] indicating that abnormalities in postreceptor signalling elements, either genetically determined or caused by regulatory mecha- 
nisms, could have a part to play. A negative crosstalk of the insulin and the leptin signalling chain seems a possible regulatory mechanism as most obese individuals have insulin resistance and hyperinsulinaemia. We aimed to investigate whether an interference of insulin and leptin signalling can be found in isolated cells and to identify potential molecular mechanisms of a possible crosstalk.

Leptin signalling is mediated by ligand-induced conformational changes of the leptin receptor which activates the intracellular signal transducing protein janus kinase-2 (JAK-2) [3, 4]. JAK-2 has intrinsic tyrosine kinase activity causing autophosphorylation and subsequently phosphorylation of the leptin receptor on different tyrosine residues [5, 6]. Downstream of JAK-2 activation of a signalling cascade similar to that of the insulin receptor occurs, e.g. phosphorylation of signal transducer and activator of transcription (STAT) proteins as well as insulin receptor substrate-1 and -2 (IRS-1, IRS-2) [7-11]. This allows molecular candidates to be identified which might connect both signal transduction pathways and might mediate a negative crosstalk.

Leptin resistance is discussed both in terms of the hypothalamic action of leptin as well as of peripheral leptin effects. It is not clear whether the peripheral hyperinsulinaemia found in obese individuals might lead to high insulin concentrations in the hypothalamus. By contrast, high local insulin concentrations in peripheral tissues, in particular in the islets of the pancreas, are very likely as chronic oversecretion is typically found in obese people. Moreover, modulation of insulin secretion by leptin in human islets has been found [12-14]. Therefore, the human beta cell is probably a target of extracranial leptin action and insulin-secreting cell lines might reflect to some extent the situation in beta cells. We used the insulin-secreting cell line RINr 1046-38 to test whether insulin interferes with the action of leptin. Our data suggest that supraphysiological insulin concentrations could induce leptin resistance in insulin-secreting cells. Our studies from transfected cell lines show that this insulin-induced leptin resistance could be due to inhibition of JAK-2 phosphorylation by a tyrosine phosphatase-dependent pathway.

\section{Materials and methods}

Materials. Cell culture reagents and fetal calf serum were purchased from Gibco (Eggenstein, Germany). Human insulin and murine recombinant leptin were provided by Hoechst AG (Frankfurt, Hessen, Germany). [ $\gamma^{32}$ P]ATP (3000 Ci/ mmol) was from DuPont NEN (Bad Homburg, Hessen, Germany) and L- $\alpha$-phosphatidylinositol from Sigma (Munich, Germany). Polyclonal antibodies against JAK-2 were purchased from Upstate Biotechnology (Lake Placid, N.Y., USA); polyclonal IRS-1 and IRS-2 antibodies were kindly provided by M.F. White (Boston, Mass., USA), monoclonal anti- phosphotyrosine antibody (PY20) was from Leinco (Ballwin, USA) and protein A sepharose from Pharmacia (Uppsala, Sweden). The reagents for SDS/PAGE and immunoblotting were purchased from Roth (Karlsruhe, Germany) and BioRad (Munich, Germany). Nitrocellulose was from Schleicher and Schuell (Dassel, Germany) and the non-radioactive enhanced chemiluminescence detection system (ECL) was obtained from Amersham (Braunschweig, Germany). The rat insulin RIA Kit (RI 13K) was purchased from Linco (St. Charles, Mo. USA).

Measurement of insulin release in RINr 1046-38 cells. RIN 1046-38 cells were plated $\left(3 \cdot 10^{4}\right.$ cells per well) into 24-well microtitre plates (Falcon, Fortworth, Tex., USA) and grown $[15,16]$. Endogenous expression of the long leptin receptor, IRS-1, IRS-2, JAK-2, SHP1 and SHP2 could be shown for RINr 1046-38 cells by RT-PCR analysis (data not shown). After the cells reached $50 \%$ confluency, they were washed in Krebs-Ringer HEPES buffer and starved for $60 \mathrm{~min}$ in the same buffer containing $1 \mathrm{mmol} / 1$ glucose and $0.1 \%$ bovine serum albumin. The cells were then incubated with insulin (1 $\mathrm{nmol} / \mathrm{l}$ insulin for $4 \mathrm{~h}$ ), the insulin containing buffer was removed and the cells were washed two times with Krebs-Ringer HEPES buffer. Subsequently, cells were stimulated with $60 \mathrm{ng} /$ $\mathrm{ml}$ leptin for $30 \mathrm{~min}$. or glucose $(3 \mathrm{mmol} / 1,30 \mathrm{~min}$.) in Krebs-Ringer HEPES buffer containing $1 \mathrm{mmol} / \mathrm{l}$ glucose and $0.1 \%$ bovine serum albumin. The supernatant was then collected to determine insulin release. To measure intracellular insulin content, cells were washed two times with Krebs-Ringer HEPES buffer and then lysed overnight with a solution containing $150 \mathrm{ml}$ absolute ethanol, $47 \mathrm{ml} \mathrm{H}_{2} \mathrm{O}$ and $3 \mathrm{ml} 10 \mathrm{~N} \mathrm{HCl}$ at $4{ }^{\circ} \mathrm{C}$. Insulin measurement from cell supernatant and lysates was done by a RIA Kit (Linco, RI 13K).

Transient expression in HEK 293 cells. Human embryonic kidney fibroblast 293 cells were grown in Dulbecco's MEM/Nutrient Mix F12 medium supplemented with $10 \%$ fetal calf serum. Cells were transfected according to the protocol of Chen and Okayama [17]. Briefly, cells were grown in 6-well dishes at a density of $3 \cdot 10^{5}$ cells per well in $2 \mathrm{ml}$ of DMEM medium. A total of $4 \mu \mathrm{g}$ supercoiled plasmid DNA was mixed with $0.25 \mathrm{~mol} / 1 \mathrm{CaCl}_{2}$ in a final volume of $0.1 \mathrm{ml}$. To this an equal amount of $2 \times$ transfection buffer $(50 \mathrm{mmol} / \mathrm{l} \mathrm{BES}$, pH 6.95 , $280 \mathrm{mmol} / \mathrm{l} \mathrm{NaCl}, 1.5 \mathrm{mmol} / \mathrm{N} \mathrm{Na}_{2} \mathrm{HPO}_{4}$ ) was added and after incubation for $10 \mathrm{~min}$ at room temperature, the mixture was given dropwise to the cells. After incubation for $16 \mathrm{~h}$ at $37^{\circ} \mathrm{C}$ and $3 \% \mathrm{CO}_{2}$ the cells were serum starved for $24 \mathrm{~h}$ in DMEM ( $1 \mathrm{~g} / \mathrm{l}$ glucose) containing $0.5 \%$ fetal calf serum.

Assay of phosphatidylinositol-3 kinase activity. After incubation with $100 \mathrm{nmol} / \mathrm{l}$ insulin for $10 \mathrm{~min}$ or with $10 \mathrm{ng} / \mathrm{ml} \mathrm{recom-}$ binant leptin for $15 \mathrm{~min}$, cells were rinsed once with ice cold PBS and lysed at $4{ }^{\circ} \mathrm{C}$ for $5 \mathrm{~min}$ in $1 \mathrm{ml}$ of lysis buffer $(50 \mu \mathrm{mol} / \mathrm{l}$ HEPES $\mathrm{pH} 7.2,150 \mathrm{mmol} / \mathrm{l} \mathrm{NaCl}, 1 \mathrm{mmol} / \mathrm{l}$ EGTA, $10 \%$ (v/v) glycerol, $1 \%(\mathrm{v} / \mathrm{v})$ Triton X-100, $100 \mathrm{mmol} / \mathrm{l} \mathrm{NaF}, 10 \mathrm{mmol} / \mathrm{l}$ sodium pyrophosphate, $100 \mu \mathrm{mol} / \mathrm{l}$ sodium orthovanadate, $1 \mathrm{mmol} / \mathrm{l} \mathrm{PMSF}, 10 \mu \mathrm{g} / \mathrm{ml}$ aprotinin). Lysates were centrifuged at $13000 \cdot g$ for $10 \mathrm{~min}$ and the supernatants were immunopurified with the indicated antibody after dilution of Triton X-100 to $0.4 \%$. The immunocomplexes were absorbed to protein A Sepharose for $2 \mathrm{~h}$. Immunoprecipitates were washed three times and pellets were directly incubated with L- $\alpha$ phosphatidylinositol $(0.1 \mathrm{mg} / \mathrm{ml})$ for $10 \mathrm{~min}$ in a solution containing $50 \mu \mathrm{mol} / \mathrm{l}\left[\gamma^{32} \mathrm{P}\right] \mathrm{ATP}, 1.2 \mathrm{mmol} / \mathrm{l}$ Na-orthovanadate, $5 \mathrm{mmol} / 1 \mathrm{MgCl}_{2}, 25 \mathrm{mmol} / \mathrm{l} \mathrm{HEPES}, \mathrm{pH} \mathrm{7.4}$, at room temperature for $10 \mathrm{~min}$ in a final volume of $50 \mu \mathrm{l}$. After addition of $20 \mu \mathrm{l} 8 \mathrm{~mol} / \mathrm{l} \mathrm{HCl}$, lipids were extracted with $160 \mu \mathrm{l}$ 
chloroform/methanol (1:1, by vol), centrifuged at $13000 \cdot g$ for 5 min and the lower phase containing the phospholipids was lyophilised and subsequently dissolved in $5 \mu \mathrm{l}$ chloroform/ methanol (1:1, by vol). The products of the reaction were separated by thin layer chromatography [9]. ${ }^{32} \mathrm{P}$-labelled phospholipids were detected by autoradiography. Standard lipids were run in parallel and detected with iodine vapour.

SDS polyacrylamide gel electrophoresis and immunoblotting. Transiently transfected HEK 293 cells and Rat-1 fibroblasts stably transfected with the human insulin receptor were serum depleted and stimulated as indicated in the Figures. Cells were then washed once with ice-cold PBS and lysed in a buffer containing protease and phosphatase inhibitors $(20 \mathrm{mmol} / \mathrm{l} \mathrm{HE}$ $\mathrm{PES}, 150 \mathrm{mmol} / \mathrm{NaCl}, 10 \%$ glycerol, $1 \%$ Triton-X-100, $1.5 \mathrm{mmol} / \mathrm{l} \mathrm{MgCl}_{2}, 4 \mathrm{mmol} / \mathrm{l}$ EGTA, $1 \mathrm{mmol} /$ EDTA, 1200 TIU/L aprotinin, $10 \mathrm{mmol} / 1 \mathrm{Na}_{4} \mathrm{P}_{2} \mathrm{O}_{7}, 2 \mathrm{mmol} / \mathrm{l} \mathrm{Na}$-orthovanadate, $100 \mathrm{mmol} / \mathrm{l} \mathrm{NaF}, 2 \mathrm{mmol} / \mathrm{l} \mathrm{PMSF}, \mathrm{pH} 7.4)$. The lysates were centrifuged at $13000 \cdot \mathrm{g}$ for $10 \mathrm{~min}$. After addition of Laemmli buffer, samples were applied to a $7.5 \%$ SDS/polyacrylamide gel. Proteins were then transferred to nitrocellulose filters by semi-dry blotting (transfer buffer: $20 \mathrm{mmol} / \mathrm{l}$ $\mathrm{NaH}_{2} \mathrm{PO}_{4}, 20 \mathrm{mmol} / 1 \mathrm{Na}_{2} \mathrm{HPO}_{4}, \mathrm{pH}$ 8.8). Filters were blocked with NET buffer $(150 \mathrm{mmol} / \mathrm{l} \mathrm{NaCl}, 5 \mathrm{mmol} / \mathrm{l}$ EDTA, $50 \mathrm{mmol} / \mathrm{l}$ TRIS, $0.05 \%$ Triton $\mathrm{X}-100$ and $0.25 \%$ gelatine, $\mathrm{pH}$ 7.4) for $1 \mathrm{~h}$. Subsequently, filters were incubated with the first antibody overnight at $4{ }^{\circ} \mathrm{C}$. The membranes were washed three times with NET buffer before they were incubated with peroxidase-conjugated anti-mouse or anti-rabbit $\mathrm{IgG}$ for $1 \mathrm{~h}$ at room temperature. Visualisation of immunocomplexes was done by enhanced chemiluminescence (ECL, Amersham).

Statistical analysis. For statistical analysis Students $t$ test was applied and a $p$ value of less than 0.05 was considered statistically significant.

\section{Results}

In this study we tested the hypothesis that leptin resistance might be aggravated by a negative crosstalk of the insulin signalling chain. We used the glucose sensitive insulinoma cell line RINr 1046-38 to evaluate whether high insulin concentrations can alter leptin effects on insulin secretion. Leptin treatment $(60 \mathrm{ng} / \mathrm{ml}$, $30 \mathrm{~min})$ stimulated insulin secretion by $35 \pm 6.3 \%$ $(n=10, p<0.001)$. Activation of insulin secretion by leptin was similar to that of $3 \mathrm{mmol} / \mathrm{l}$ glucose (Fig. 1). Preincubation of these cells with insulin $(1 \mathrm{nmol} / \mathrm{l}$, $4 \mathrm{~h}$ ) could cancel the action of leptin. As a control, insulin incubation for $4 \mathrm{~h}$ alone had no substantial effect on insulin secretion. This therefore suggests that high insulin concentrations interfere with leptin signal transduction in insulin-secreting cells. The insulinoma cell line RINr 1046-38, which we studied, contains low amounts of insulin and leptin signal transduction proteins and is therefore not suitable for addressing the mechanism of a crosstalk between the insulin and leptin signalling pathway. We used instead HEK293 cells which express the long isoform of the leptin receptor and the PI 3-kinase [9]. To ensure that the signalling proteins which were overexpressed during the course

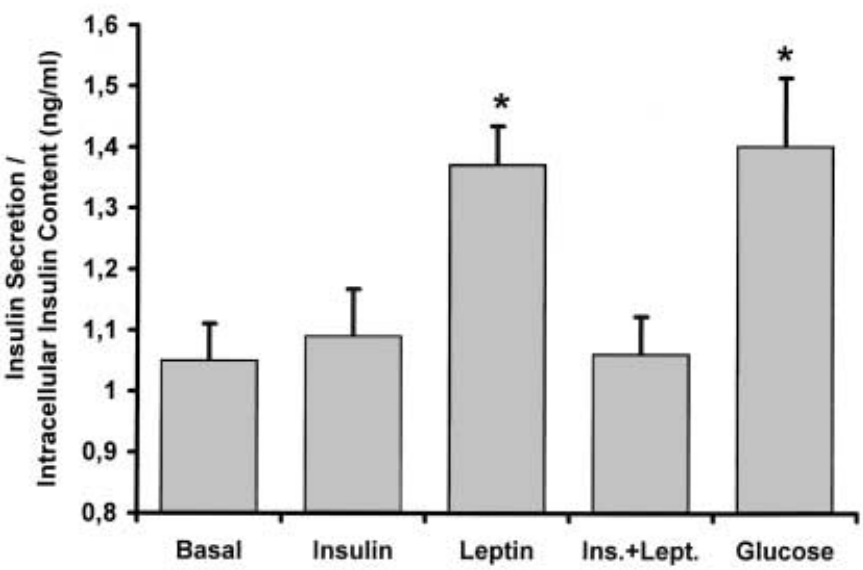

Fig. 1. RINr 1046-38 cells were plated into 24 -well microtitre plates and grown until they reached $50 \%$ confluency. Cells were starved for $60 \mathrm{~min}$. and then incubated for $4 \mathrm{~h}$ with or without $1 \mathrm{nmol} / \mathrm{l}$ insulin in Krebs-Ringer HEPES buffer with $1 \%$ bovine serum albumin. Insulin was washed off before stimulation with $60 \mathrm{ng} / \mathrm{ml}$ leptin for $30 \mathrm{~min}$. or glucose $(3 \mathrm{mmol} / \mathrm{l}$, 30 min.) in Krebs-Ringer HEPES buffer containing $1 \%$ bovine serum albumin and $1 \mathrm{mmol} / \mathrm{l}$ glucose. After that time the buffer was collected for determination of insulin release. For the measurement of intracellular insulin content the cells were lysed as described in the methods. (Student's $t$ test, $* p<0.001$ )

of our study in HEK293 cells are also expressed in RINr 1046-38 cells, we performed polymerase chain reaction and confirmed the presence of the corresponding mRNAs (data not shown).

To study insulin and leptin-stimulated PI 3-kinase activity the signal-transducing proteins JAK-2 and IRS-2 were transiently overexpressed in HEK 293 cells because both signalling elements were important for leptin stimulated PI 3-kinase activation [9]. HEK 293 cells were starved and stimulated with leptin or insulin. Whole cell lysates were immunoprecipitated with JAK-2 antibodies and the immunocomplexes, coupled to Sepharose beads, were subjected to PI 3-kinase assay. In HEK 293 cells overexpressing JAK-2 and IRS-2 as intracellular signalling proteins, leptin but not insulin was able to stimulate JAK-2-associated PI 3-kinase activity by $2.1 \pm 0.46$-fold (Fig. 2, left side, $n=3$ ). To investigate whether the insulin signal interferes with the action of leptin on PI 3-kinase we transfected HEK 293 cells with JAK-2, IRS2 and HIR. Co-overexpression of the human insulin receptor (HIR) abolished the effect of leptin on the PI 3-kinase which can be seen in Figure 2 (right side). In addition, preincubation with insulin (1 $\mathrm{nmol} / \mathrm{l}, 4 \mathrm{~h}$ ) reduced leptin-stimulated and JAK-2-associated PI 3-kinase activity in the absence of insulin receptor overexpression (lower part of Figure 2), again suggesting that the insulin signal interferes with leptin-stimulated PI 3-kinase.

We then studied whether insulin is also able to reduce leptin-stimulated JAK-2 phosphorylation up- 

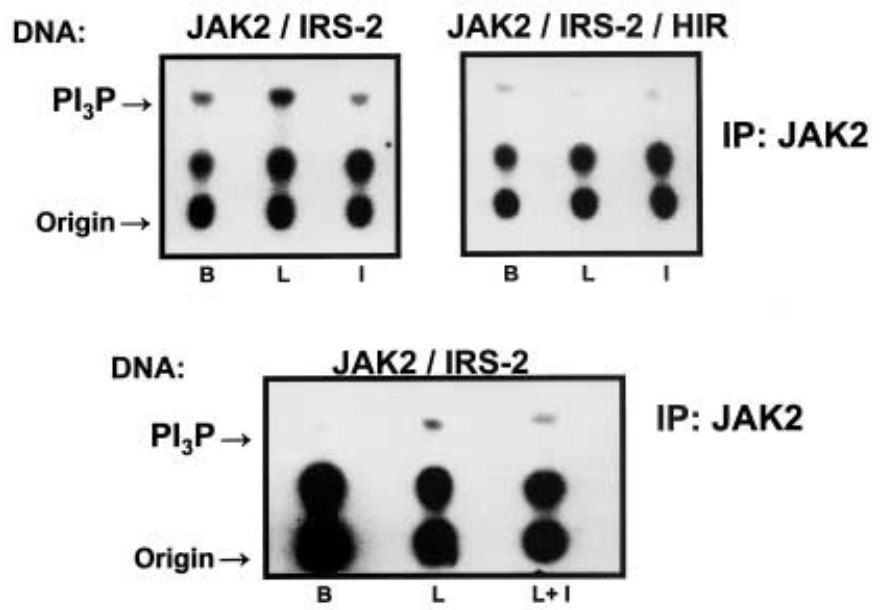

Fig. 2. HEK 293 fibroblasts overexpressing JAK-2 and IRS-2 together with (right side) or without (left side) the human insulin receptor were stimulated with $10 \mathrm{ng} / \mathrm{ml}$ leptin (L) for $15 \mathrm{~min}$ or $100 \mathrm{nmol} / \mathrm{l}$ insulin (I) for $10 \mathrm{~min}$ at $37^{\circ} \mathrm{C}$ or left untreated (B). The lower part of Fig. 2 shows JAK-2-associated PI 3-kinase activity from HEK 293 cells overexpressing JAK2 and IRS-2 which were preincubated with or without $1 \mathrm{nmol} /$ 1 insulin for $4 \mathrm{~h}$ before leptin stimulation $(10 \mathrm{ng} / \mathrm{ml}, 15 \mathrm{~min})$. Whole cell lysates were incubated with anti-JAK-2 antibodies. PI 3-kinase was assayed in the immunoprecipitates and ${ }^{32} \mathrm{P}$-incorporation into phosphatidylinositol was visualized by separation of the labelled phospholipids on thin layer chromatography plates and autoradiography

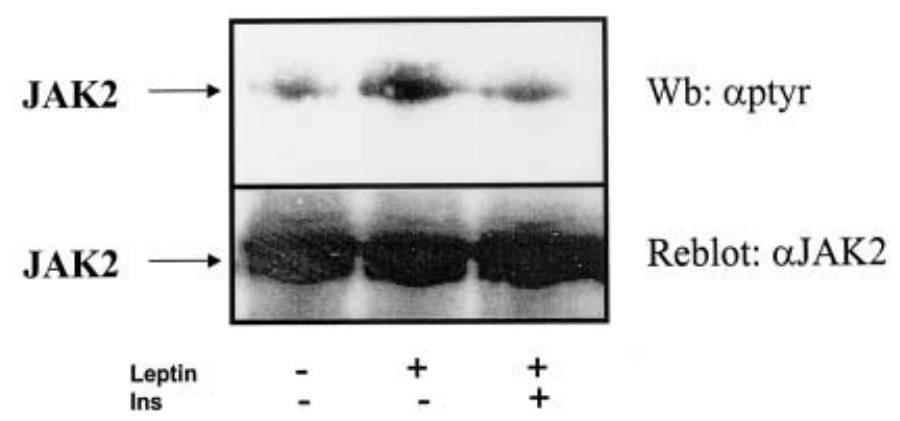

Fig. 3. HEK 293 cells overexpressing JAK-2 were preincubated with or without insulin $(4 \mathrm{~h}, 1 \mathrm{nmol} / \mathrm{l})$ and then stimulated with leptin $(30 \mathrm{~min}, 60 \mathrm{ng} / \mathrm{ml})$ at $37^{\circ} \mathrm{C}$. Whole cell lysates were prepared, proteins were separated by SDS-PAGE, transferred to nitrocellulose and blotted with antibodies detecting phosphotyrosine (ptyr). To prove that similar amounts of protein were overexpressed the filters were reblotted with antibodies against JAK-2 (lower part)

stream of PI 3-kinase. HEK 293 cells were transiently transfected with JAK-2 and in analogy to the RIN 1046-38 experiment preincubated with insulin (1 $\mathrm{nmol} / \mathrm{l}, 4 \mathrm{~h}$ ) and subsequently stimulated with leptin $(60 \mathrm{ng} / \mathrm{ml}, 30 \mathrm{~min})$. Proteins of whole cell lysates were separated by SDS-PAGE and transferred to nitrocellulose. JAK-2 phosphorylation was detected by immunoblotting with anti-phosphotyrosine antibodies (upper panel of Figure 3). To ensure that similar amounts of proteins were expressed, the nitrocel-

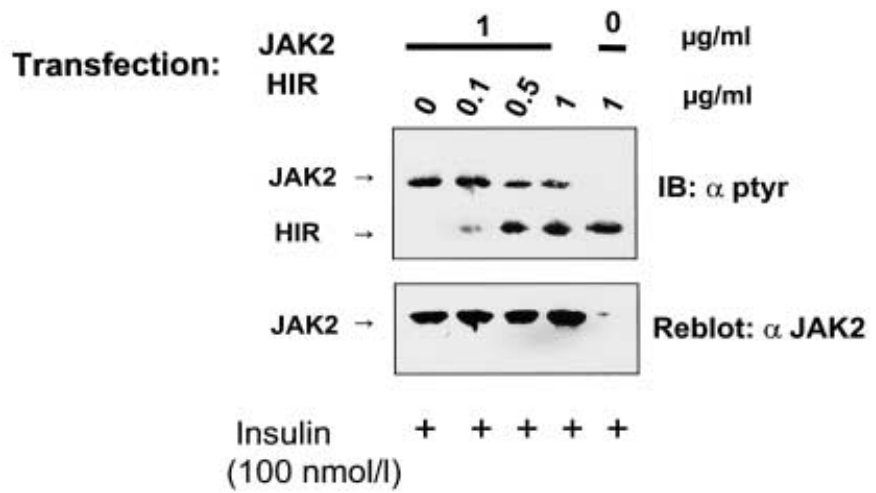

Fig.4. The effect of co-overexpression of different amounts of the human insulin receptor together with JAK-2 was tested. HEK 293 cells were transiently transfected with different amounts of insulin receptor DNA $(0-1 \mu \mathrm{g} / \mathrm{ml})$ together with or without JAK-2 $(1 \mu \mathrm{g} / \mathrm{ml})$ as indicated. Cells were stimulated with $100 \mathrm{nmol} / \mathrm{l}$ insulin for $5 \mathrm{~min}$ at $37^{\circ} \mathrm{C}$. Whole cell lysates were prepared, the proteins were separated by SDS-PAGE, transferred to nitrocellulose and blotted with anti-phosphotyrosine antibodies to detect tyrosine phosphorylation of JAK-2 and the insulin receptor (IR). Filters were reblotted with antiJAK-2 antibodies to detect the overexpressed protein level (lower panel)

lulose filter was reblotted with JAK-2 antibody (lower panel of Figure 3). Transient expression of JAK-2 in HEK 293 cells caused tyrosine phosphorylation already in the basal state which is in agreement with other reports $[18,19]$. This JAK-2 phosphorylation could be further increased by leptin stimulation by $2.06 \pm 0.54$-fold $(n=3, p<0.05)$. Preincubation of HEK 293 cells with insulin, however, abolished the effect of leptin on JAK-2 phosphorylation which suggests that insulin interferes with the action of leptin even at the level of JAK-2.

To clarify if this insulin-induced cellular leptin resistance is mediated by the insulin receptor signalling network, we tested whether overexpression of the insulin receptor reduced JAK-2 phosphorylation in HEK 293 cells. Co-overexpression of JAK-2 with the human insulin receptor could reduce basal JAK2 phosphorylation (Fig. 4). This effect was more pronounced with increased expression of the insulin receptor suggesting that the insulin signalling network is involved in reduced JAK-2 phosphorylation. To find out if this effect is specific for the insulin receptor, we co-overexpressed the EGF- and the PDGF receptor with JAK-2. Whole cell lysates were subjected to SDS-PAGE and subsequently immunoblotted with anti-phosphotyrosine antibodies. We measured autophosphorylation of the different tyrosine kinase receptors and that of JAK-2 (Fig. 5). In contrast to the human insulin receptor, the PDGF-receptor was not able to reduce tyrosine phosphorylation of JAK-2. After overexpression of the EGF receptor JAK-2 phosphorylation was slightly reduced $(40 \pm 12 \%$ inhibition, $n=3$ ) but the insulin receptor was much 


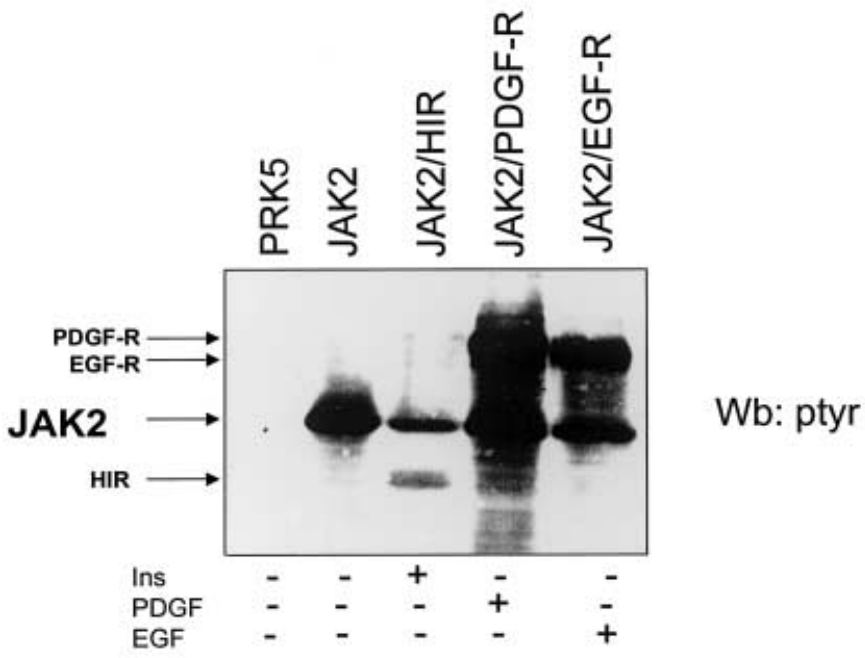

Fig. 5. HEK 293 cells were transfected as indicated. PRK5, expression vector; JAK-2, janus kinase-2,; HIR, human insulin receptor; PDGF-R, platelet derived growth factor receptor,; EGF-R, epidermal growth factor receptor. Cells were stimulated for $5 \mathrm{~min}$ with $100 \mathrm{nmol} / \mathrm{l}$ insulin, EGF or PDGF. Whole cell lysates were prepared, the proteins were separated by SDSPAGE, transferred to nitrocellulose and blotted with antiphosphotyrosine. The positions of JAK-2, PDGF-R, EGF-R and HIR are indicated by arrows

A)

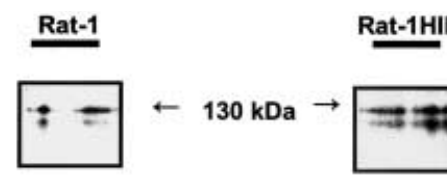

B)

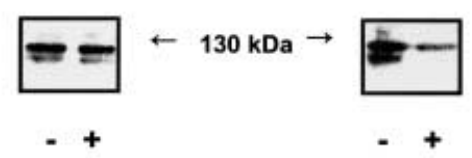

IP: $\alpha$ JAK 2 IB: $\alpha$ JAK 2

IP: $\alpha$ JAK 2 IB: $\alpha$ ptyr

INS (100 nmol/l)
Fig.6 A, B. Parental rat-1 fibroblasts (Rat-1) and cells stably overexpressing the human insulin receptor (Rat-1 HIR) were stimulated with $100 \mathrm{nmol} / \mathrm{l}$ insulin for $5 \mathrm{~min}$ at $37^{\circ} \mathrm{C}$. Cells were lysed and proteins were immunoprecipitated with JAK2 antibody. Immunoprecipitates were washed and separated by SDS-PAGE. Proteins were transferred to nitrocellulose filters which were blotted either with anti-JAK-2 antibodies (A) or with anti-phosphotyrosine antibodies (B)

more active ( $82 \pm 21 \%$ inhibition, $n=7)$ than the EGF receptor. Thus, the reduction of JAK-2 phosphorylation in HEK 293 cells seems to be specific to the insulin receptor signal.

To rule out unspecific protein interaction after transient transfection in HEK 293 cells, we studied rat-1 fibroblasts which were stably transfected with the human insulin receptor (rat-1 HIR). Endogenous JAK-2 expression and phosphorylation was detected after immunoprecipitation with polyclonal JAK-2 antibodies. JAK-2 could be visualized by immunoblotting with JAK-2 antibodies (Fig. 6). Phosphorylation of JAK-2, detected by reblotting of the

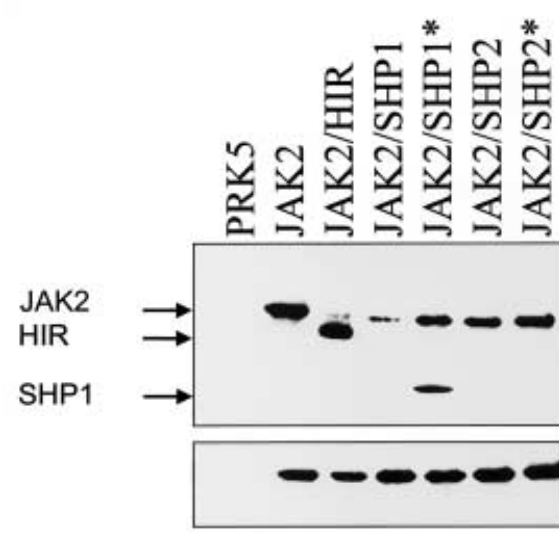

IB: $\alpha p t y r$

Fig. 7. Total cell lysates of HEK 293 cells overexpressing JAK2 alone or together with the human insulin receptor (HIR) or the tyrosine phosphatases SHP-1 and SHP-2 in its active or catalytically inactive $(*)$ form were applied to SDS-PAGE. As a control the PRK5 vector was transiently transfected. After SDS-PAGE, proteins were transferred to nitrocellulose and blotted with phosphotyrosine antibodies (upper panel). The presence of similar amounts of protein was verified by reprobing the nitrocellulose with JAK-2 antibodies (lower panel)

same nitrocellulose with an anti-phosphotyrosine antibody, could be found even in the unstimulated state. Insulin reduced the phosphorylation of JAK-2 only in insulin receptor overexpressing rat-1 cells. This suggests again that the reduction of JAK-2 phosphorylation was induced by the insulin receptor signal.

Enzymes with the potential to reduce JAK-2 phosphorylation are the phosphatases SHP-1 and SHP-2 because both are associated with JAK-2 and can be activated by the insulin receptor [20]. Furthermore, evidence is given that both phosphatases can associate with JAK-2 which may result in activation of the catalytic domain $[18,21]$. SHP-2 has also been shown to bind to the phosphorylated leptin receptor which inhibits JAK-2 phosphorylation $[5,6]$. Therefore, we investigated if SHP-1 or SHP-2 can mediate the effect of the insulin signal on JAK-2 phosphorylation in HEK 293 cells. Overexpression of JAK-2 alone and together with the active or inactive form of the tyrosine phosphatases SHP-1 or SHP-2 was performed. Immunoblot analysis showed that overexpression of SHP-1 induced JAK-2 dephosphorylation to a similar degree as the insulin receptor $(84 \pm 25 \%, n=6, p<0.05)$. This was confirmed by the expression of a catalytically inactive form of SHP-1 which hardly inhibited JAK-2 phosphorylation (Figure 7). In contrast, SHP-2 was much less able to provoke dephosphorylation of JAK-2 after overexpression in HEK 293 cells. Tyrosine phosphorylation of SHP-1 by JAK-2 can only be observed with the catalytically negative SHP-1 which is not able to auto-dephosphorylate. In contrast to SHP-1, we were not able to detect tyrosine phosphorylation of SHP-2 in our experimental setting. 


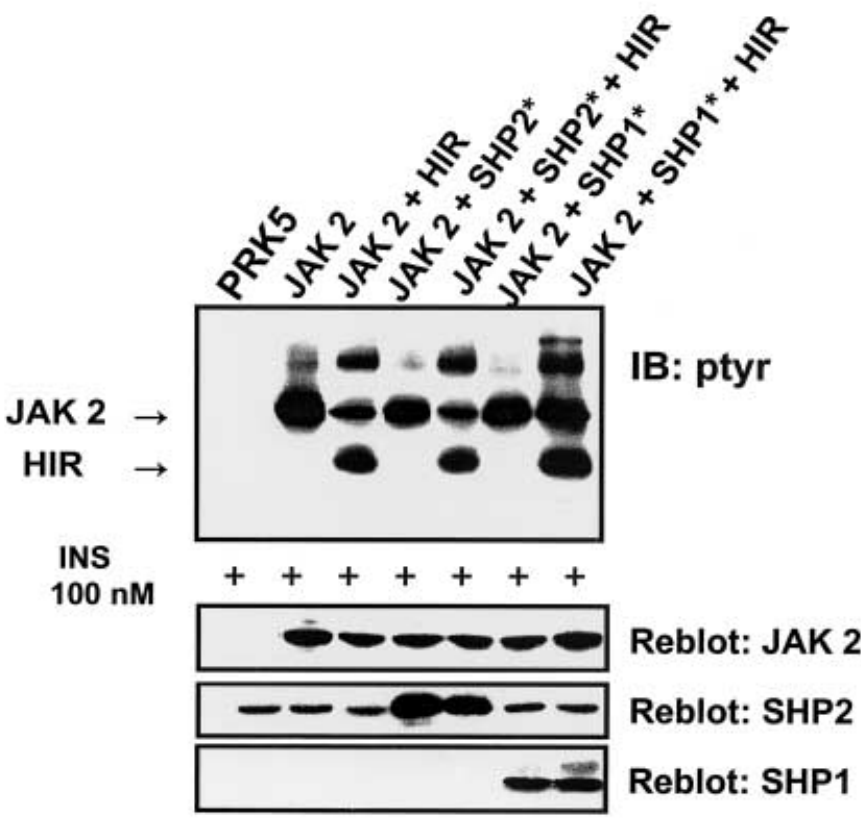

Fig. 8. The impact of the tyrosine phosphatases SHP-1 and SHP-2 on the inhibitory effect of insulin on JAK-2 phosphorylation was tested. HEK 293 cells were transfected with the PRK5 vector (left side), with JAK-2 alone or together with the human insulin receptor expression plasmid with or without a catalytically inactive (*) SHP-1 or SHP-2. Cells were stimulated with $100 \mathrm{nmol} / \mathrm{l}$ insulin for $5 \mathrm{~min}$ at $37^{\circ} \mathrm{C}$. Whole cell lysates were prepared, the proteins were separated by SDSPAGE, transferred to nitrocellulose and blotted with antibodies against phosphotyrosine to detect tyrosine phosphorylation of JAK-2 and the insulin receptor $\beta$-subunit (HIR). Filters were reblotted with JAK-2, SHP-2 and SHP-1 antibodies (lower panel) to measure the amount of overexpressed proteins

Because SHP-1 could dephosphorylate JAK-2 in HEK 293 cells, we assessed if the inhibitory effect of the insulin receptor on JAK-2 was mediated by SHP-1. Studies were done in HEK 293 cells overexpressing JAK-2, the insulin receptor and a catalytically inactive form of SHP-1. In addition, overexpression of catalytically inactive SHP-2 was used as a control. The catalytically inactive form of SHP-1 could partially prevent the effect of the insulin receptor on JAK-2 phosphorylation but SHP-2 had no major effect on JAK-2 dephosphorylation provoked by the insulin receptor (Fig.8).

\section{Discussion}

To address the question of a cross talk between leptin- and insulin signalling pathways, we studied the effects of leptin on insulin secretion as well as the consequences of pretreatment of cells with insulin. In addition we used HEK293 cells as model systems to follow the interaction of specific proteins. The data obtained in the insulin-secreting cell lines suggest that insulin could negatively regulate leptin sig- nalling. Effects of leptin on insulin-secreting cells have been described by many investigators $[12,13$, 22-32] and the majority of these in-vitro studies suggest that leptin inhibits insulin secretion $[12,13$, 22-30]. This conclusion, however, is in conflict with in vivo data from obese individuals. Despite high leptin levels hypersecretion of insulin and hyperinsulinaemia is found in obese humans. Preincubation of RINr 1046-38 cells with high insulin levels completely cancelled the effect of leptin on insulin secretion. This suggests that the insulin signalling pathway could interfere with leptin signalling and could cause leptin resistance in insulin-secreting cells. It is not clear if analogous effects could be induced in different cell models reflecting other target tissues of leptin action. Furthermore insulin concentrations used do not reflect the physiological in-vivo situation. We tested the effects of insulin at a concentration of 1 nmol/l which exceeds the concentrations circulating in obese individuals. Therefore, extrapolation of our data to the in vivo situation in peripheral target tissues of leptin action and in particular to the hypothalamus might not be appropriate. However, a different situation might exist for the pancreatic beta cell because very high local levels of insulin are reached in the islets of individuals who are in a state of chronic hypersecretion [33].

Our data from insulinoma cells indicate that hyperinsulinaemia itself could cause or aggravate leptin resistance in an autocrine way if very high insulin concentrations are reached in local islets [33]. Our data agrees with studies on mice lacking the insulin receptor or insulin receptor substrate-1 in pancreatic beta cells $[34,35]$. In these animal models, interruption of the insulin signalling pathway in beta cells resulted in failure of glucose-dependent insulin secretion as well as lower fat mass and leptin. This suggests that mice which are defective in insulin signalling of peripheral tissues are more sensitive towards the action of leptin.

Our studies in HEK 293 and rat-1 cells show that insulin could interfere with leptin signalling at the level of JAK-2. We found reduced leptin-dependent phosphorylation of JAK-2 after incubation with high insulin concentrations. Our data suggest that this effect of insulin is mediated, at least partly, by the phosphatase SHP-1. There is evidence that the homologous tyrosine phosphatases SHP-1 and SHP-2 associate with JAK-2 as well as with the insulin receptor $[18,21,36,37]$. Association of SHP-1 with the insulin receptor occurs at the C-terminal region of SHP-1 and results in phosphorylation of SHP-1 on tyrosine 538 which could activate the phosphatase [36]. Moreover, the N-terminal region of SHP-1 can interact with JAK-2 [18]. A direct association of SHP-1 with JAK-2 caused activation of the phosphatase and subsequent dephosphorylation of JAK-2 [18]. In addition, inhibition of leptin-induced JAK-2 phosphory- 


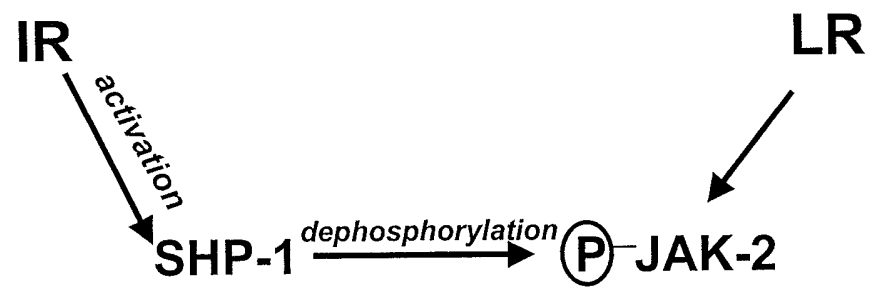

reduced signal

Fig.9. Model for the signalling pathway leading to reduced leptin signalling

lation by SHP-2 has been reported [5, 6]. SHP-2 was activated upon leptin stimulation and reduced JAK2 phosphorylation and STAT3-mediated gene induction $[5,6]$. A negative feedback of the leptin signal through activation of SHP-2 could therefore be possible. We have now shown that SHP-1 could also lead to JAK-2 dephosphorylation. A potential model for the insulin signalling pathway leading to reduced JAK-2 phosphorylation is given in Figure 9.

In summary, our data suggest that high insulin levels can induce leptin resistance in RINr 1046-38 cells. We investigated possible molecular mechanisms for this effect in HEK 293 cells and rat-1 fibroblasts. Our studies suggest that the insulin signal interferes with JAK-2 phosphorylation and that SHP-1 is, at least partly involved in the negative effect of the insulin receptor on JAK-2. Therefore, hyperinsulinaemia in obese individuals could lead to an aggravation of leptin resistance by this molecular mechanism. In this case high insulin levels would be positively correlated with leptin levels independent of the body weight. This has already been shown by some investigators [38-40] but it is not clear whether a cycle of hyperinsulinaemia-induced peripheral leptin resistance with insufficient suppression of pancreatic insulin release really exists in obese patients.

Acknowledgements. This work was supported by a grant from the Deutsche Forschungsgemeinschaft (DFG) to M. Kellerer (Ke 553-6). We thank J. Ertl, Aventis, Frankfurt, for the generous gift of mouse recombinant leptin and H.P.T. Ammon, Pharmacology, University of Tübingen, for helpful discussion. We are indebted to E. Metzinger, E. Seffer and J. Mushack for excellent technical assistance and manuscript preparation.

\section{References}

1. Friedman JM, Halaas JL (1998) Leptin and the regulation of body weight in mammals. Nature 395: 763-770
2. Maffei M, Stoffel M, Barone M et al. (1996) Absence of mutations in the human $\mathrm{OB}$ gene in obese/diabetic subjects. Diabetes 45: 679-682

3. Tartaglia LA, Dembski M, Weng X et al. (1995) Identification and expression cloning of a leptin receptor, OB-R. Cell 83: $1263-1271$

4. Tartaglia LA (1997) The leptin receptor. J Biol Chem 272: 6093-6096

5. Carpenter LR, Farruggella TJ, Symes A, Karow ML, Yancopoulos GD, Stahl N (1998) Enhancing leptin response by preventing $\mathrm{SH} 2$-containing phosphatase 2 interaction with Ob receptor. Proc Natl Acad Sci U S A 95: 6061-6066

6. Li C, Friedman JM (1999) Leptin receptor activation of $\mathrm{SH} 2$ domain containing protein tyrosine phosphatase 2 modulates ob receptor signal transduction. Proc Nat Acad Sci USA 96: 9677-9682

7. Szanto I, Kahn, CR (2000) Selective interaction between leptin and insulin signaling pathways in a hepatic cell line. Proc Natl Acad Sci U S A 97: 2355-2360

8. Bjorbaek C, Uotani S, daSilva B, Flier JS (1997) Divergent signaling capacities of the long and short isoforms of the leptin receptor. J Biol Chem 272: 32686-32695

9. Kellerer M, Koch M, Metzinger E, Mushack J, Capp E, Haring HU (1997) Leptin activates PI-3 kinase in C2C12 myotubes via janus kinase-2 (JAK-2) and insulin receptor substrate-2 (IRS-2) dependent pathways. Diabetologia 40: 1358-1362

10. Baumann H, Morella KK, White DW et al. (1996) The fulllength leptin receptor has signaling capabilities of interleukin 6-type cytokine receptors. Proc Natl Acad Sci U S A 93: 8374-8378

11. Vaisse C, Halaas JL, Horvath CM, Darnell-JE J, Stoffel M, Friedman JM (1996) Leptin activation of Stat3 in the hypothalamus of wild-type and ob/ob mice but not $\mathrm{db} / \mathrm{db}$ mice. Nat Genet 14: 95-97

12. Kulkarni RN, Wang ZL, Wang RM et al. (1997) Leptin rapidly suppresses insulin release from insulinoma cells, rat and human islets and, in vivo, in mice. J Clin Invest 100: 2729-2736

13. Fehmann HC, Berghofer P, Brandhorst D et al. (1997) Leptin inhibition of insulin secretion from isolated human islets. Acta Diabetol 34: 249-252

14. Haffner SM, Miettinen H, Mykkanen L, Stern MP (1998) Leptin concentrations are associated with higher proinsulin and insulin concentrations but a lower proinsulin/insulin ratio in non-diabetic subjects. Int J Obes Relat Metab Disord 22: 899-905

15. Asfari M, Janjic D, Meda P, Li G, Halban PA, Wollheim CB (1992) Establishment of 2-mercaptoethanol-dependent differentiated insulin-secreting cell lines. Endocrinology 130: $167-178$

16. Clark SA, Burnham BL, Chick WL (1990) Modulation of glucose-induced insulin secretion from a rat clonal betacell line. Endocrinology 127: 2779-2788

17. Chen CA, Okayama H (1988) Calcium phosphate-mediated gene transfer: a highly efficient transfection system for stably transforming cells with plasmid DNA. Biotechniques 6: 632-638

18. Jiao HY, Berrada K, Yang WT, Tabrizi M, Platanias LC, Yi TL (1996) Direct association with and dephosphorylation of Jak2 kinase by the SH2-domain-containing protein tyrosine phosphatase SHP-1. Mol Cell Bio 16: 6985-6992

19. Yamamoto K, Quelle FW, Thierfelder WE et al. (1994) Stat4, a novel gamma interferon activation site-binding protein expressed in early myeloid differentiation. Mol Cell Bio 14: 4342-4349 
20. Kharitonenkov A, Schnekenburger J, Chen Z et al. (1995) Adapter function of protein-tyrosine phosphatase 1D in insulin receptor/insulin receptor substrate-1 interaction. J Biol Chem 270: 29189-29193

21. Fuhrer DK, Feng GS, Yang YC (1995) Syp associates with gp130 and Janus kinase 2 in response to interleukin-11 in 3T3-L1 mouse preadipocytes. J Biol Chem 270: 24826-24830

22. Fehmann HC, Peiser C, Bode HP et al. (1997) Leptin: A potent inhibitor of insulin secretion. Peptides 18: 1267-1273

23. Seufert J, Kieffer TJ, Leech CA et al. (1999) Leptin suppression of insulin secretion and gene expression in human pancreatic islets: Implications for the development of adipogenic diabetes mellitus. J Clin Endocrinol Metab 84: 670-676

24. Ahren B, Havel PJ (1999) Leptin inhibits insulin secretion induced by cellular cAMP in a pancreatic B cell line (INS1 cells). Am J Physiol 277: R959-R966

25. Harvey J, McKenna F, Herson PS, Spanswick D, Ashford MLJ (1997) Leptin activates ATP-sensitive potassium channels in the rat insulin-secreting cell line, CRI-G1. J Physiol (Lond) 504: 527-535

26. Zhao AZ, Bornfeldt KE, Beavo JA (1998) Leptin inhibits insulin secretion by activation of phosphodiesterase 3B. J Clin Invest 102: 869-873

27. Kieffer TJ, Keller RS, Leech CA, Holz GG, Habener JF (1997) Leptin suppression of insulin secretion by the activation of ATP-sensitive $K+$ channels in pancreatic betacells. Diabetes 46: 1087-1093

28. Ookuma M, Ookuma K, York DA (1998) Effects of leptin on insulin secretion from isolated rat pancreatic islets. Diabetes 47: 219-223

29. Seufert J, Kieffer TJ, Habener JF (1999) Leptin inhibits insulin gene transcription and reverses hyperinsulinemia in leptin-deficient ob/ob mice. Proc Natl Acad Sci U S A 96: 674-679

30. Chen NG, Swick AG, Romsos DR (1997) Leptin constrains acetylcholine-induced insulin secretion from pancreatic islets of ob/ob mice. J Clin Invest 100: 1174-1179
31. Shimizu H, Ohtani K, Tsuchiya Tet al. (1997) Leptin stimulates insulin secretion and synthesis in HIT-T 15 cells. Peptides 18: 1263-1266

32. Tanizawa Y, Okuya S, Ishihara H, Asano T, Yada T, Oka Y (1997) Direct stimulation of basal insulin secretion by physiological concentrations of leptin in pancreatic beta cells. Endocrinology 138: 4513-4516

33. Ammon HP, Reiber C, Verspohl EJ (1991) Indirect evidence for short-loop negative feedback of insulin secretion in the rat. J Endocrinol 128: 27-34

34. Kulkarni RN, Winnay JN, Daniels M et al. (1999) Altered function of insulin receptor substrate-1-deficient mouse islets and cultured beta-cell lines. J Clin Invest 104: R69-R75

35. Kulkarni RN, Bruning JC, Winnay JN, Postic C, Magnuson MA, Kahn CR (1999) Tissue-specific knockout of the insulin receptor in pancreatic beta cells creates an insulin secretory defect similar to that in type 2 diabetes. Cell 96: 329-339

36. Uchida T, Matozaki T, Noguchi T et al. (1994) Insulin stimulates the phosphorylation of Tyr538 and the catalytic activity of PTP1C, a protein tyrosine phosphatase with Src homology-2 domains. J Biol Chem 269: 12220-12228

37. Kharitonenkov A, Schnekenburger J, Chen ZJ et al. (1995) Adapter function of protein-tyrosine phosphatase 1D in insulin receptor insulin receptor substrate-1 interaction. J Biol Chem 270: 29189-29193

38. Donahue RP, Prineas RJ, Donahue RD et al. (1999) Is fasting leptin associated with insulin resistance among nondiabetic individuals? The Miami Community Health Study. Diabetes Care 22: 1092-1096

39. Zimmet PZ, Collins VR, de-Courten MP et al. (1998) Is there a relationship between leptin and insulin sensitivity independent of obesity? A population-based study in the Indian Ocean nation of Mauritius. Mauritius NCD Study Group. Int J Obes Relat Metab Disord 22: 171-177

40. Kim MH, Yamaguchi T, Katakura T (1997) Serum leptin levels are associated with hyperinsulinemia independent of body mass index but not with visceral obesity. Biochem Biophys Res Commun 239: 340-344 